\title{
A novel hemostatic scaffold material and the importance of scaffold formation on ending hemorrhage: An experimental rat study
}

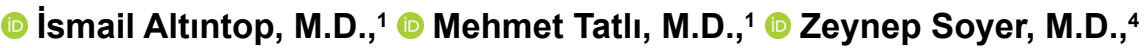 \\ (D) Arzu Hanım Yay, M.D., ${ }^{5}$ ๑ Ahmet Öztürk, M.D., ${ }^{3}$ ๑ Çiğdem Karakükçü, M.D. ${ }^{2}$
}

\begin{abstract}
${ }^{1}$ Department of Emergency Medicine, University of Health Science, Kayseri Training and Research Hospital, Kayseri-Turkey ${ }^{2}$ Department of Biochemistry, University of Health Science, Kayseri Training and Research Hospital, Kayseri-Turkey ${ }^{3}$ Department of Biostatistics, Erciyes University Faculty of Medicine, Kayseri-Turkey

${ }^{4}$ Erciyes University, Hakan Çetinsaya Experimantal Animal Center, Kayseri-Turkey

${ }^{5}$ Department of Histology and Embryology, Erciyes University Faculty of Medicine, Kayseri-Turkey
\end{abstract}

\begin{abstract}
BACKGROUND: Different pharmacological agents are developed to control bleeding. However, it is critical for these agents to induce thrombin formation and have an effect on vasoconstriction, coagulation, and scaffold. In this study, we aimed to demonstrate the agents' ability to stop bleeding properties on minor and major open bleedings after skin clefts, extracorporal injuries, traumatic cuts, spontaneous or surgical intervention besides scaffold properties. For this purpose, a new and authentic hemostatic agent, processed diatomite (PD) and the most preferred chitosan in the medical area were used to test blood stopping and scaffold effects in a rat femoral bleeding model. The samples were examined by scanning electron microscopy (SEM), and the results on blood stopping were shared.
\end{abstract}

METHODS: The current experimental study was conducted on rats. The effects of hemostatic agents on our femoral bleeding model were determined. In this study, 22 male Wistar albino rats weighing 158-215 g, were used. The rats were assigned randomly to three groups: control group $(n=6)$, chitosan group $(n=8)$, and PD group $(n=8)$. Bleeding time, scaffold formation, weight differences, histopathological effect and scanning electron microscope (SEM) analyses were performed.

RESULTS: In our experimental model, weight loss was $5.0 \pm \mathrm{l} .3 \mathrm{~g}$ for the control group, $2.9 \pm \mathrm{I} . \mathrm{I} \mathrm{g}$ for the chitosan group, and $2.7 \pm \mathrm{I} .0$ $\mathrm{g}$ for the PD group, respectively. When weighed before and after the experiment, there was a significant change in weights of rats in chitosan, and PD groups regarding scaffold formation: it was complete for six rats (75\%) and weak for two (25\%) rats in chitosan group; however, it was complete for seven rats $(87.5 \%)$ and weak for one $(12.5 \%)$ rat in the PD group. Scaffold formation was significant for the chitosan and PD groups versus the control group $(p=0.002)$.

CONCLUSION: In our study, the scaffold formed by PD exerts appropriate porousness and contributes to fibrin formation and prevent re-bleeding. PD had a strong and significant scaffold effect. The effectiveness of PD to stop bleeding was equal to chitosan. Besides being natural, hemostatic agents should not induce cellular damage. We histopathologically demonstrated that PD was harmless for the natural structure of cells and vessels in the femoral site.

Keywords: Chitosan; diatomite; hemostatic agent; scaffold.

\section{INTRODUCTION}

Uncontrolled hemorrhages constitute nearly half of the deaths in the military zone and also are the second cause of deaths due to trauma in the field of health. ${ }^{[1,2]}$ Hemorrhages are composed of injury owing to trauma, war and disaster injuries, stab injuries, nose hemorrhages and post-burn hemorrhages. ${ }^{[2,3]}$ Regardless of the dimension and type, it is crucial

Cite this article as: Altıntop İ, Tatlı M, Soyer Z, Yay AH, Öztürk A, Karakükçü Ç. A novel hemostatic scaffold material and the importance of scaffold formation on ending hemorrhage: An experimental rat study. Ulus Travma Acil Cerrahi Derg 2020;26:163-170.

Address for correspondence: İsmail Altintop, M.D.

Sağlık Bilimleri Üniversitesi Kayseri Eğitim ve Araştırma Hastanesi, Acil Tıp Anabilim Dalı, Kayseri, Turkey

Tel: +90 352 - 3368884 E-mail: draltintopl@hotmail.com

Ulus Travma Acil Cerrahi Derg 2020;26(2):163-170 DOI: 10.14744/tjtes.2019.34359 Submitted: 01.07.2018 Accepted: 12.03.2019 Online: 24.02.2020

Copyright 2020 Turkish Association of Trauma and Emergency Surgery 
to stop the hemorrhage in early states. Similarly, bleedings due to surgical procedures should be intervened immediately. The insufficiency in homeostasis may induce different hemorrhagic complications. ${ }^{[3,4]}$ Bleedings may represent a wide spectrum: from a leakage type hemorrhage and the surgical incision site to hemorrhages with a requirement of transfusion and even disturbing organ functions with a hemorrhagic shock, which ultimately cause the patient's death. ${ }^{[3,4]}$ The most common hemorrhages are the extracorporeal ones..$^{[5,6]}$ In the USA, nearly $1 / 3$ of 6 million deaths due to trauma depend on hemorrhages. ${ }^{[6]}$ Of those, half of the cases could not reach a hospital setting and died of uncontrolled hemorrhage. ${ }^{[6]}$ It is critical to intervene in the hemorrhages owing to trauma in health and military fields properly and correctly.

Hemostatic agents are used widely in the world not only to stop hemorrhage but also to form a scab on the wound as well. In recent years, the most preferred local hemostatic agent was chitosan. Chitosan is a biomaterial produced from the salts found in fossils of oyster shells in oceans. ${ }^{[7,8]}$

The term "scaffold" is used in many medical areas. It is especially defined as a fibrin structure, fibrin matrix in closing the wound site. ${ }^{[9,10]}$ After the cessation of hemorrhage, the scab is called scaffold. ${ }^{[10,1]]}$ The scaffold structure is composed of blood elements, thrombocytes and the applied hemostatic agent. ${ }^{[10-13]}$ The pore dimension of the scaffold, surface area and porousness are accepted as important parameters in tissue engineering. ${ }^{[12]}$ In the scaffold structure, the morphology of pore wall, the connection between the pores, cell culture, migration, volume transfer, growth, gene expression and new tissue formation in three dimensions are the most studied issues in recent years. ${ }^{[1,13]}$ The clinical use of biological scaffold materials becomes widespread. Scaffold surgical mesh materials are primarily used to construct extracellular matrix integrity. In the current study, we used processed diatomite (PD). Diatomite is a fossil-type sedimentary rock formed by the accumulation of the crusts, including silica of diatoms, the aquatic creatures belonging to the algae genus. ${ }^{[14,15]}$ Diatom is a very little protoplasm living in its own crust or shell made up of silica provided from the water. In nature, it becomes fossil by natural processes. The natural product is obtained by only the drying of crude diatomite and removing foreign materials. The diatomite used in this study is processed diatomite (PD), and it is used as a hemostatic agent after pre-treatment. Besides the hemostatic trait of PD, we searched its effects on blood stopping by forming scaffold's continuity. For this purpose, we compared the effects of chitosan and PD in the femoral hemorrhage model in rats to contribute to the current literature.

\section{MATERIALS AND METHODS}

All the procedures with animals in this study were approved by the local Ethical Committee of Erciyes University Experimental Research and Application Center-HADYEK (Approval date: 14.12.2016 and number: 16/52). By obtaining additional ethical approval, we evaluated the scaffold structures. In this study, 22 male Wistar albino rats weighing $158-215 \mathrm{~g}$, were used. After their first controls, the animals were accommodated under standard experimental animal housing conditions with controlled temperature $\left(2 \mathrm{I} \pm 2^{\circ} \mathrm{C}\right)$, humidity

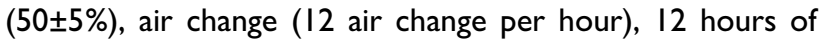
light and darkness and ad libitum feed. Each cage contained three rats and provided coarse sawdust bedding. The rats were assigned randomly to three groups: control group $(n=6)$, chitosan group $(n=8)$, and PD group $(n=8)$. For the control group $(n=6)$, the hemorrhage site was directly compressed with gauze without any hemostatic agent. For the chitosan group $(n=8)$, direct pressing was applied with chitosan. For the PD group, direct pressing was applied with PD. Before the experiments, ketamine and xylazine hydrochloride were prepared for anesthesia. The inguinal site of the rat was trimmed and cleaned with octenisept ${ }^{\circledR}$ for the femoral artery and vein hemorrhage model. Skin and subcutaneous tissue were dissected to demonstrate the femoral artery and vein. Hemorrhage was performed by the entire incision of the femoral artery and vein. The hemorrhage was stopped by the concurrent application of the hemostatic material with gauze dressing (Celox ${ }^{\circledR}$ or PD). For all the applications, a standard weight of $200 \mathrm{~g}$ was used as pressure on the hemorrhage site. First, hemorrhage control was performed at 60 seconds and controlled every 30 seconds. Hemorrhage time was recorded (BST), and the pressure was terminated. The scaffold structures on the hemorrhage site were collected in sterile containers. The surface morphology of microparticles related to scaffold structures (PD, chitosan) was observed by a scanning electron microscope (SEM). The aluminum foil loaded with microparticles were coated with gold metal under vacuum and afterward examined by SEM (EVOLS25, Zeiss, Germany).

In the current study, the diatomite-processed diatomite (PD) underwent some stages and pre-treated for the hemostatic effects. These stages were as follows: washing with hydrogen peroxide ( $100 \mathrm{~mL} / 1000 \mathrm{~g})$, dried at $35^{\circ} \mathrm{C}$ for 2 hours, stirred for 24 hours in aqueous media and dried, separation of dusts and foreign materials after drying, calcination at $700^{\circ} \mathrm{C}$, dried at $35^{\circ} \mathrm{C}$ for 6 hours after cooling, adjustment of $\mathrm{pH}$ at 5.59.0 , sterilization and preparation for ready-to-use. The prepared material in the powder form was used.

\section{SEM Analyses}

The surface morphology of microparticles related to scaffold structures (PD, chitosan) was observed by a scanning electron microscope (SEM). The aluminum foil loaded with microparticles were coated with gold metal under vacuum and afterward examined using SEM (EVOLS25, Zeiss, Germany).

\section{Histopathological Evaluation}

For this study, formalin-fixed and paraffin-wax embedded samples were obtained from the vessels of all rats. For routine histological examination, wound site tissues taken from rats and 


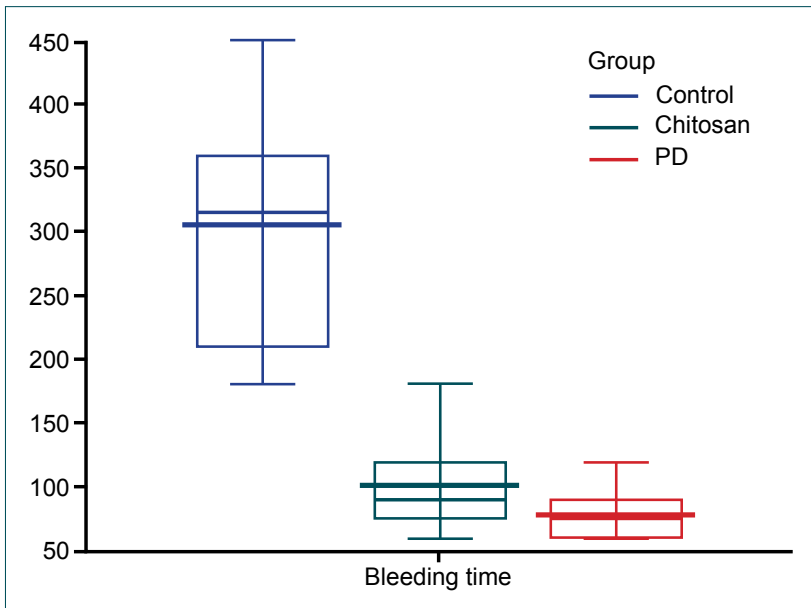

Figure 1. The box-plot graphics of hemorrhage time $(\min )$ for the control, chitosan and PD groups.

solved in formaldehyde (10\%) were used. Then, dehydrated in a gradient ethanol series and cleaned in xylene and embedded in paraffin. For each sample, $5 \mu \mathrm{M}$ paraffine sections were cut. After deparaffinization and rehydration, all sections were colored with Masson trichrome. The morphological evaluation of the samples was performed, and photographs were taken with a photomicroscope (Olympus BX-5I, Tokyo, Japan).

\section{Statistical Analyses}

The normality of the data was assessed using the Shapiro Wilk normality test and Q-Q graphs. Data were expressed as numbers for categorical variables and mean $\pm S D$ for continuous variables. Comparisons between groups were performed using One-Way ANOVA Analysis of Variance (post-hoc test: Tukey). The chi-square test was used to reveal to relation

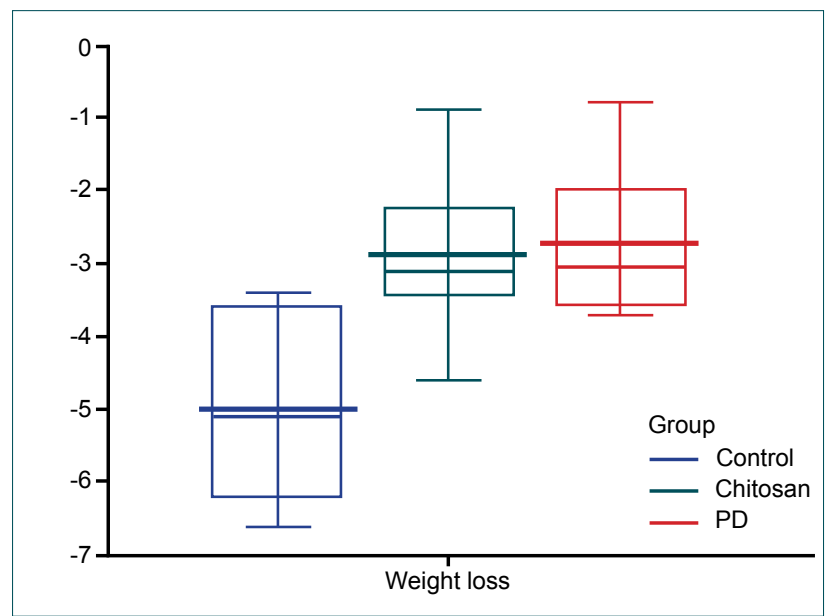

Figure 2. The box-plot graphics of weight loss for the control, chitosan and PD groups before and after experiment.

with scaffold and bleeding after scaffolding within groups. Analyses were conducted using Turcosa Cloud (Turcosa Ltd Co, Turkey) statistical software. A p-value of less than $5 \%$ was considered statistically significant.

\section{RESULTS}

After modeling for rat hemorrhage, hemorrhage time boxplot graphics for the control, chitosan and PD groups are given in Figure I. In Figure 2, hemorrhage loss for all groups was demonstrated. Accordingly, hemorrhage times were significantly decreased in the PD and chitosan groups versus the control group (Table I). The highest weight loss after hemorrhage was detected in the control group, while the loss was significantly decreased in the PD and chitosan groups (Table I).

Table I. Distribution of variables by groups

\begin{tabular}{|c|c|c|c|c|}
\hline \multirow[t]{3}{*}{ Continues variables } & \multicolumn{3}{|c|}{ Groups } & \multirow[t]{3}{*}{$\mathbf{p}$} \\
\hline & Control $(n=6)$ & Chitosan $(n=8)$ & Processed diatomite $(n=8)$ & \\
\hline & Mean $\pm S D$ & Mean $\pm S D$ & Mean \pm SD & \\
\hline Weight difference & $5.0 \pm 1.3 a$ & $2.9 \pm 1.1^{b}$ & $2.7 \pm 1.0^{\mathrm{b}}$ & 0.003 \\
\hline Bleeding time & $305.0 \pm 99.3^{\mathrm{a}}$ & $101.3 \pm 39.1^{b}$ & $78.8 \pm 22.3^{b}$ & $<0.001$ \\
\hline Categorical variables & n (\%) & n (\%) & n (\%) & $\mathbf{p}$ \\
\hline \multicolumn{5}{|l|}{ Scaffold formation } \\
\hline Complete & $0(0)^{a}$ & $6(75)^{b}$ & $7(87.5)^{b}$ & 0.002 \\
\hline Weak & $6(100)$ & $2(25)$ & I (12.5) & \\
\hline \multicolumn{5}{|l|}{ Bleeding after scaffold } \\
\hline+ & $6(100)^{a}$ & $4(50)^{\mathrm{ab}}$ & $\mathrm{I}(12.5)^{\mathrm{b}}$ & 0.006 \\
\hline- & $0(0)$ & $4(50)$ & $7(87.5)$ & \\
\hline
\end{tabular}

Data $\mathrm{n}(\%)$, mean \pm SD or average. According to multiple comparison tests (Tukey), groups with different superscript letters were found to have statistically significant differences. Post power: Power of performed test with alpha $(0.05)$ for bleeding time, weight difference, Scaffold formation and Bleeding after scaffold $=0.99,0.89,0.90$ and 0.85 , respectively. a: Statistically significantly different from other groups. b: Statistically significantly different from control group. 


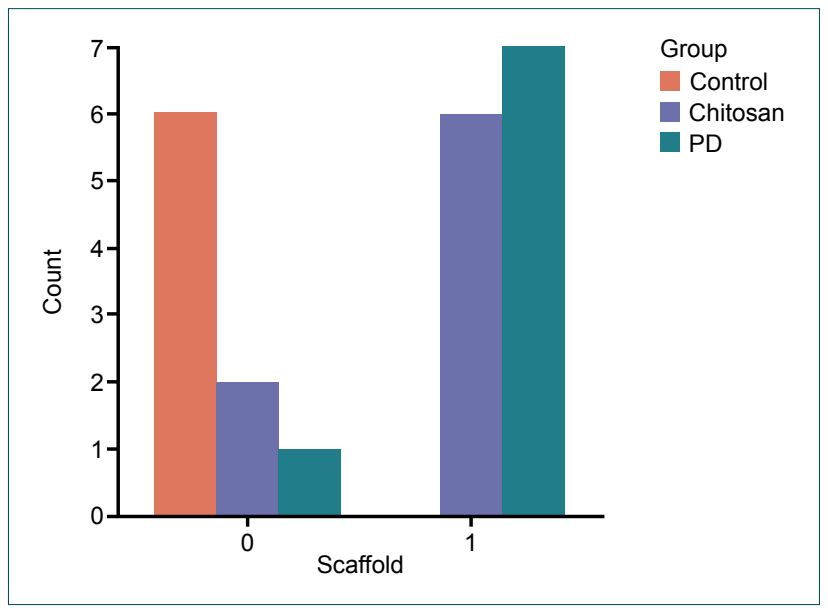

Figure 3. The graphics of the scaffold formation (0: no formation 1: weak formation).

Scaffold formation after hemorrhage model for rats in all groups is given in Figure 3. There was no scaffold formation in the control group. The highest scaffold formation was in chitosan and PD groups. Hemorrhage formation after scaffold removal is shown in Figure 4.

In Table I, the weight difference, bleeding time, scaffold formation and hemorrhage after scaffold for rats were given before and after the experiment. The weight loss in the control group was the maximum.

When the control group versus the chitosan and PD groups were compared concerning the difference in weight, the difference was significant. The mean weight loss was $5.0 \pm 1.3$ $\mathrm{g}$ in the control group, $2.9 \pm \mathrm{I} . \mathrm{I} \mathrm{g}$ in the chitosan group and $2.7 \pm \mathrm{I} .0 \mathrm{~g}$ in the PD group, respectively $(\mathrm{p}=0.003)$ (Table I).

Scaffold formation was compared between groups and evaluated as weak or complete scaffold formation. In the control group, for all rats, scaffold formation was weak. However, in the chitosan group, scaffold formation was complete for six (75\%) rats and weak for two $(25 \%)$ rats. In the PD group, the scaffold formation was complete for seven $(87.5 \%)$ rats and weak for one $(12.5 \%)$ rat. There was a significant difference between control versus chitosan and PD groups $(p=0.002)$. After removing scaffold from the wound site, hemorrhage sta-

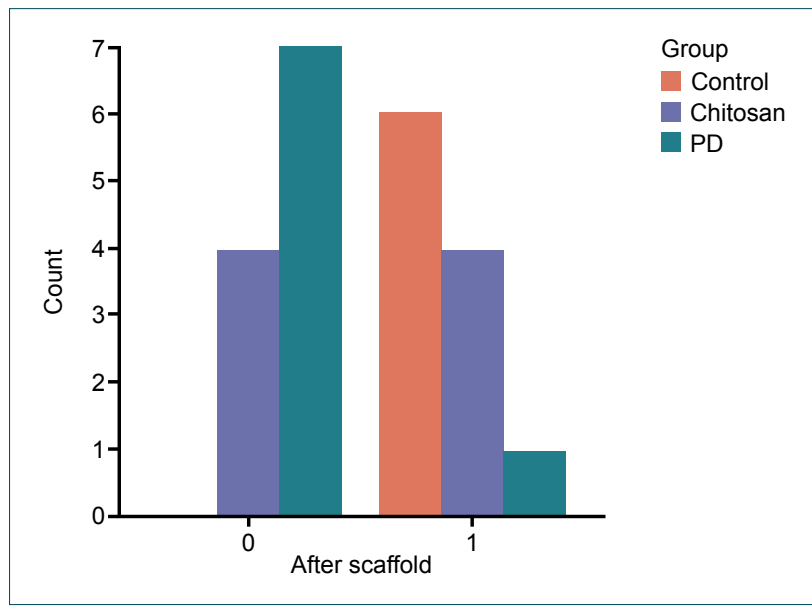

Figure 4. The distribution graphics of the hemorrhage formation after scaffold.

tus was evaluated and in the control group, all rats had bleeding. In contrast, bleeding was detected in four (50\%) rats in the chitosan group and only one (12.5\%) rat in the PD group, respectively. In conclusion, no bleeding $(n=7,87.5 \%)$ sign despite the removal of scaffold was significant $(p=0.006)$ (Table I).

The demonstration of PD in powder form used for rats, dissection of femoral site and formation of the femoral artery and vein hemorrhage, application of PD agent on hemorrhage site, removing of scaffold formation from wound site is shown in Figure 5.

For histological examination and determining the vessel structure, Masson trichrome coloring technique is used. The histological section of femoral veins of control, chitosan and PD groups are shown in Figures 6, 7 and 8, respectively.

The complete section of the images demonstrates all sections of the veins in the femoral site. The general structure of femoral veins is standard in all groups. Only in the control group, where the hemorrhage was stopped by surgical sponge, hemorrhage sites other than veins were detected. These hemorrhage sites were not observed in PD and chitosan groups. Again in all groups, endothelium, media, and adventitia were not affected by the treatment on blood vein walls. The contraction of smooth muscles and the circular ap-
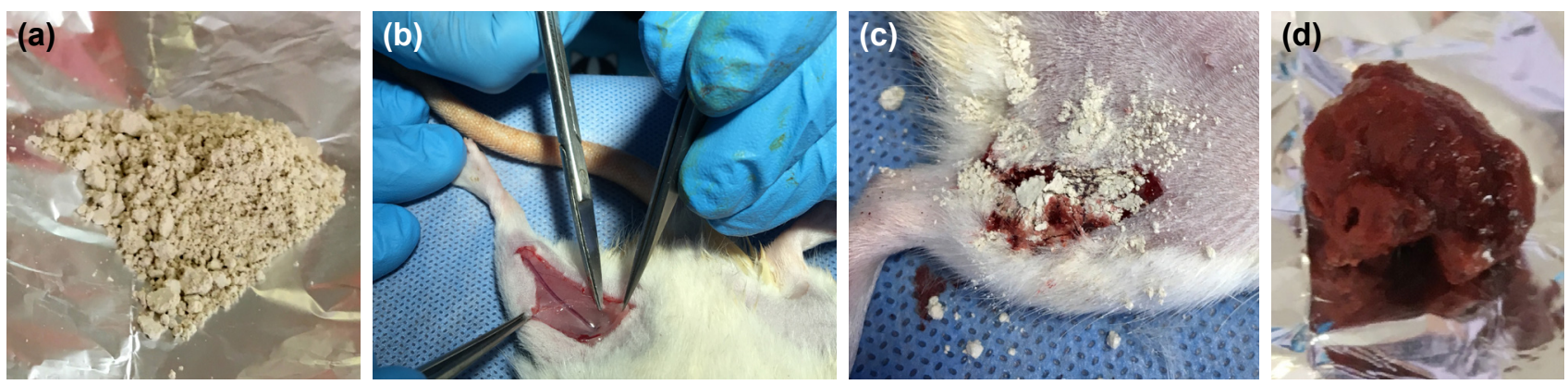

Figure 5. (a) Powder form of the PD agent. (b) Dissection of the femoral site and hemorrhage formation in femoral artery and vein. (c) Application of the PD agent on hemorrhage site. (d) Removing of the scaffold formation from wound site. 

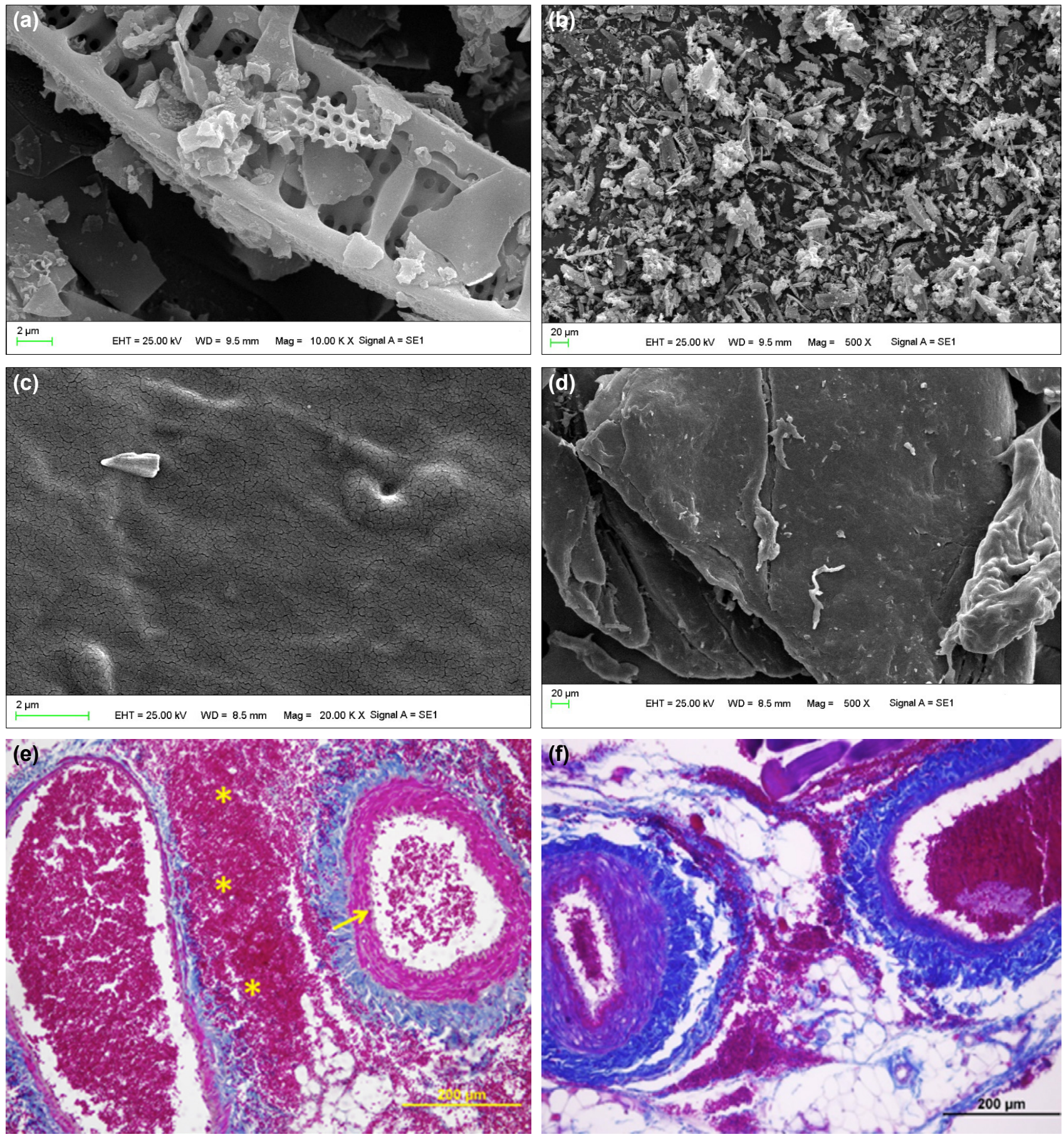

Figure 6. The scaffold imaging by SEM analysis. The surface morphology of microparticles for scaffold structure (PD, chitosan) was analyzed using SEM. (a, b) Are the SEM images of scaffold structures formed by PD. (c, d) Are the SEM images of scaffold structures formed by chitosan. (c, d) Demonstrates the microscopic image of the cut of the rat femoral artery and vein for hemorrhage model and pressure application with a surgical sponge for three minutes until the hemorrhage stops. The freely leaking blood in the control group formed clot during sample collection (star: hemorrhage site, arrow: inner elastic lamina, Masson's trichrome, original magnification x20).

pearance are given in Figure 6. In Figure 8, the intense fold of inner elastic lamina for hemorrhage control with PD is given.

\section{DISCUSSION}

Foremost in emergency services, as well as in ambulances and in clinics, the control of hemorrhage is crucial. The in- sufficiency in homeostasis may induce many complications, including massive bleeding and death. ${ }^{\left[{ }^{[1]}\right]}$ Several kinds of hemorrhage may come across: from a leakage type hemorrhage from the surgical incision area to hemorrhages with need of transfusion and even disturbing organ functions with haemorrhagic shock and ultimately cause the patient's death. In 
the field of medicine, many hemostatic agents are used. ${ }^{[1,16]}$ In the current study, chitosan, the mostly used hemostatic agent in recent years, is used. ${ }^{[17-19]}$ As being a natural product, chitosan is produced from the salts formed from the fossiles of oyster shells living in oceans. There are some difficulties in its use. ${ }^{[2]}$ We searched the effects of new hemostatic agen$t-P D$ on scaffold formation and stopping hemorrhage and compared with chitosan. The most important factor in controlling hemorrhage is fibrin formation. The fibrin formed in the hemorrhagic area is called as scaffold. The hemorrhage is bestly controlled by the strength of scaffold structure. In the literature, there are studies on the strengthening of fibrin and bioabsorbable fibrin. Yasuda et al., ${ }^{[1]}$ with bioabsorbable fibrin matrix model, detected minimal absorption in cranial region and dura mater. We planned PD for extracellular use and cleaning from wound site after bleeding without any absorption. Thus, we examined the regional effects of PD. After bleeding modelling in rats, scaffold formation was given in Figure 3. Accordingly, there was no scaffold formation in the control group. No scaffold formation was less in PD group than the chitosan group. In Tong et al.'s. ${ }^{[10]}$ study on diabetic rats, they revealed that the sponge they produced by chitosan constituted an ideal scaffold on wound site. Similarly, although we detected successful scaffold formation with chitosan, the highest scaffold formation was observed with PD. The most important characteristic of scaffold formation is its contribution to a permanent process for bleeding ending. ${ }^{[11,12]}$ In our bleeding model, we demonstrated the presence of bleeding after removing of the scaffold in Figure 4 . In the current literature, the majority of the studies focused on the duration spent on ending bleeding because wound repair will be necessary after ending of bleeding. No bleeding should occur after removal of hemostatic agent from the wound site, so an ideal repairment starts after surgical procedures and treatments. In the current study, there was bleeding after surgical dressing removal in all rats in the control group and bleeding was continued until the bleeding stops. In chitosan and PD groups, there was non-significant bleeding.
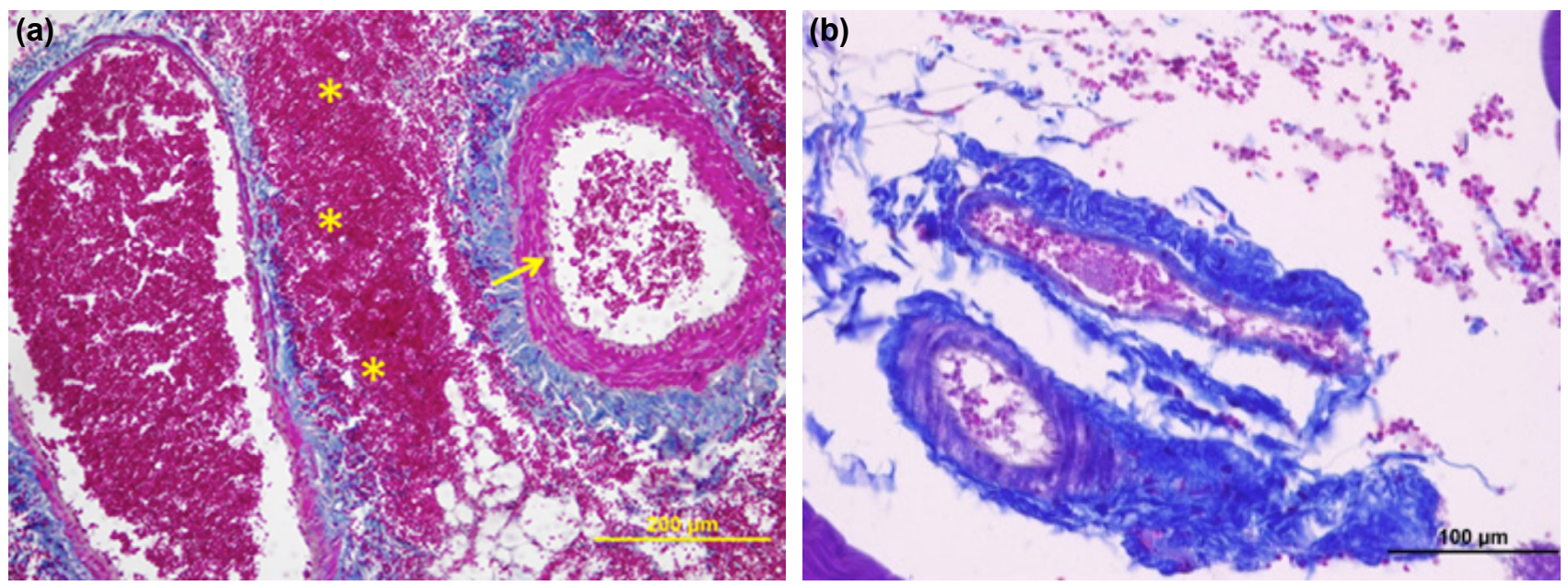

Figure 7. (a, b) The inner fold of inner elastic lamina significant with its round shape in chitosan group is given (star: hemorrhage site, arrow: inner elastic lamina, Masson's trichrome, original magnification x20).
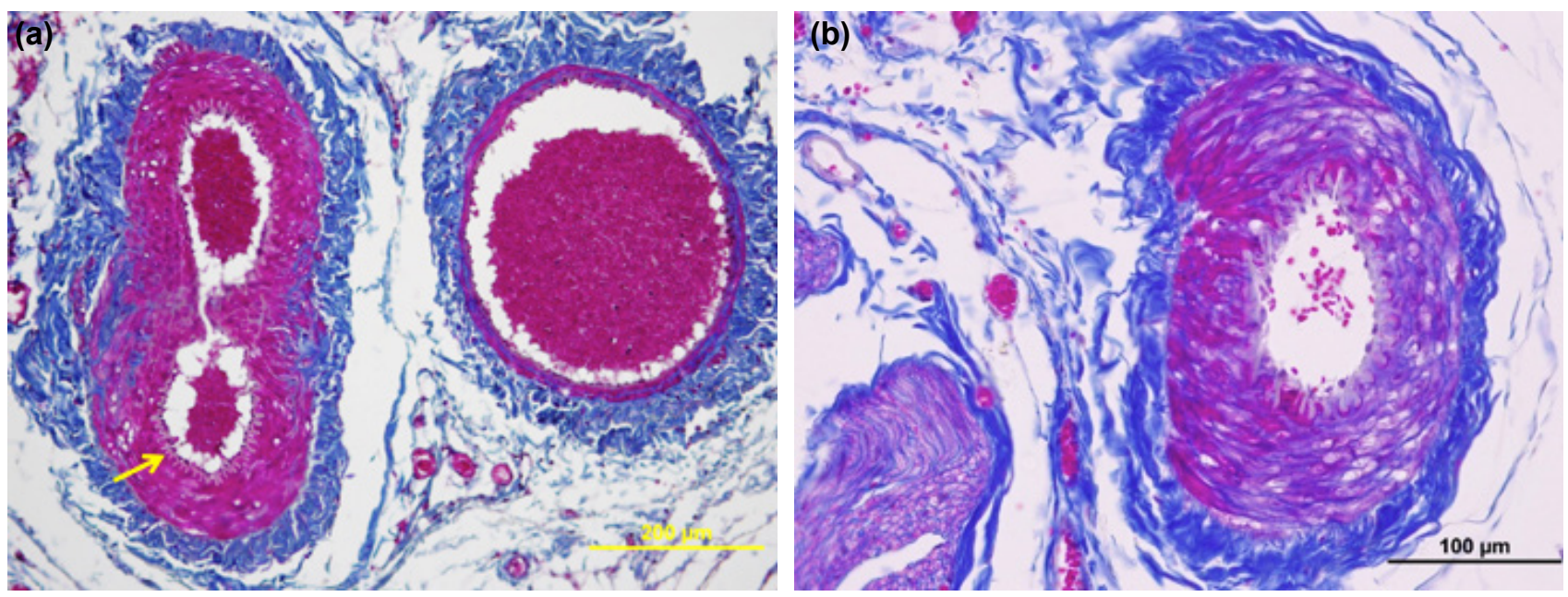

Figure 8. (a, b) Hemorrhage stops in a few minutes by the applied agent which induced complete obstruction in the vein in PD group (star: hemorrhage site, arrow: inner elastic lamina, Masson's trichrome, original magnification x20). 
It is difficult to detect bleeding time in rats. Thus, the bleeding time may only be calculated by intermediary controls for the ending of bleeding. Dikme et al., ${ }^{[20]}$ determined oxycellulose powder to be efficient in ending bleeding in rats. Similar to our study, Crofton et al. ${ }^{[21]}$ used the powder form of chitosan directly on the bleeding site and found it successful. In our study, both chitosan and PD were successful in ending bleeding versus the control group. You et al., ${ }^{[5]}$ by using a powdered form of a medical glue including aldehyde dextran and $\varepsilon$-poly (L-lysine), detected bleeding time as 174.2 seconds. In the current study, we detected bleeding time for chitosan and PD groups as $101.3 \pm 39$.I and $78.8 \pm 22.3$ seconds, respectively.

It is important to stop bleeding in case of emergency but also toxic haemostatic agent should not be used and no cellular damage should be caused when stopping bleeding. In our bleeding model treated with PD, we histopathologically examined the femoral sites. We revealed that PD had no effect on femoral vessels, and the vessels preserved the natural form of the cellular structure (Fig. 4). In sites other than bleeding site, we demonstrated that endothelin, media and adventitial regions were not affected. Our SEM analyses revealed PD, with the porous structure and high absorbing capacity, as a hemostatic agent supporting the scaffold structure. Zhang et al. ${ }^{[22]}$ used diatomite and mesalamine as carriers for gastrointestinal nanoprednisone and successfully tested it for an experimental model. Terracciano et al. ${ }^{[23]}$ evaluated the effects of diatomite in cytotoxicity tests and stated to be an available material. According to our histological evaluation, PD did not induce damage to the natural structure at the wound site and was concordant with the data in the current literature (Fig. 4). Hemostatic agents, including fibrinogen (Fibrin Glue, Tissel, Berilast, Hemaseal, and Crosseal), bovine albumin and glutaraldehyde (BioGlue), had toxic characteristics compared to topical hemostatic agents. [24,25] Plant-based hemostatic agents (Arista and HemoStase) induce thrombocyte and serum protein concentration at the application site. ${ }^{[24,26]}$ Due to protein denaturation, with these agents, wound healing delays and microemboli may occur. ${ }^{[24,26]}$ PD, besides its hemostatic properties, may be improved as a hemostatic agent and be preferred for its harmless effects on the histopathologic structure.

The hemostatic agents with compression and stopper effects exert their effects solely by their mechanic effect on the vessel after pressure. These agents do not possess bleeding ending characteristics. ${ }^{[27]}$ When gelatine group drugs, belonging to anastomotic glue group, contact with the blood protein gelatine bloats and induce clotting by thrombin and mechanical effects. ${ }^{[27]}$ In our study, we revealed by SEM analyses that PD and chitosan have roles by forming a scaffold structure contribute to mechanic fibrin.

In the current literature, various agents are used for ending bleeding. Eryilmaz et al., ${ }^{[28]}$ in their study performed with zeolite-based QuikClot, determined a tendency to diminish bleeding; however, they failed to stop bleeding completely. In the same study, the researchers emphasized the insufficiency of clinic tests. According to the first studies conducted with the bentonite-a type of zeolite, it had an effect on stopping bleeding. In their research using bentonite Acosta et al., ${ }^{[29]}$ besides decreasing bleeding and bleeding time, it may also affect ending bleeding. However, several studies pointed out the toxic effects of zeolite derivatives. Thus, differing from natural agents as being a non-zeolite derivative, PD, an algae fossil, was used for similar effects. ${ }^{[30]}$ New studies are required on PD.

\section{Conclusion}

PD had strong and significant scaffold effects. PD compound was detected as effective as chitosan for controlling bleeding. The agents used for ending bleeding should be natural and also should not induce cellular damage. We histopathologically demonstrated that PD did not impair the natural structure of cells and vessels in the femoral site.

Ethics Committee Approval: Approved by the local ethics committee.

\section{Peer-review: Internally peer-reviewed.}

Authorship Contributions: Concept: I.A., M.T.; Design: I.A., Z.S., A.H.Y.; Supervision: I.A., M.T.; Fundings: I.A.; Materials: I.A., Z.S., Ç.K.; Data: I.A., A.H.Y., A.Ö.; Analysis: I.A., A.Ö., Ç.K.; Literature search: I.A., M.T.; Writing: I.A.; Critical revision: I.A., A.Ö.

Conflict of Interest: None declared.

Financial Disclosure: Financial support has been received from the Ministry of Health Kayseri Training and Research Hospital.

\section{REFERENCES}

1. Grissom TE, Fang R. Topical hemostatic agents and dressings in the prehospital setting. Curr Opin Anaesthesiol 2015;28:210-6. [CrossRef]

2. Barnard J, Millner R. A review of topical hemostatic agents for use in cardiac surgery. Ann Thorac Surg 2009;88:1377-83. [CrossRef]

3. Spotnitz WD, Burks S. Hemostats, sealants, and adhesives: components of the surgical toolbox. Transfusion 2008;48:1502-16. [CrossRef]

4. Kozen BG, Kircher SJ, Henao J, Godinez FS, Johnson AS. An alternative hemostatic dressing: comparison of CELOX, HemCon, and QuikClot. Acad Emerg Med 2008;15:74-81. [CrossRef]

5. You KE, Koo MA, Lee DH, Kwon BJ, Lee MH, Hyon SH, et al. The effective control of a bleeding injury using a medical adhesive containing batroxobin. Biomed Mater 2014;9:025002. [CrossRef]

6. Howe N, Cherpelis B. Obtaining rapid and effective hemostasis: Part I. Update and review of topical hemostatic agents. J Am Acad Dermatol 2013;69:659.e1-17. [CrossRef]

7. Dai T, Tegos GP, Burkatovskaya M, Castano AP, Hamblin MR. Chitosan acetate bandage as a topical antimicrobial dressing for infected burns. Antimicrob Agents Chemother 2009;53:393-400. [CrossRef]

8. Muzzarelli RA. Chitins and chitosans as immunoadjuvants and non-allergenic drug carriers. Mar Drugs 2010;8:292-312. [CrossRef]

9. Ellis-Behnke RG, Liang YX, Tay DK, Kau PW, Schneider GE, Zhang $\mathrm{S}$, et al. Nano hemostat solution: immediate hemostasis at the nanoscale. Nanomedicine 2006;2:207-15. [CrossRef] 
10. Tong C, Hao H, Xia L, Liu J, Ti D, Dong L, et al. Hypoxia pretreatment of bone marrow-derived mesenchymal stem cells seeded in a collagen-chitosan sponge scaffold promotes skin wound healing in diabetic rats with hindlimb ischemia. Wound Repair Regen 2016;24:45-56. [CrossRef]

11. Yasuda H, Kuroda S, Shichinohe H, Kamei S, Kawamura R, Iwasaki Y. Effect of biodegradable fibrin scaffold on survival, migration, and differentiation of transplanted bone marrow stromal cells after cortical injury in rats. J Neurosurg 2010;112:336-44. [CrossRef]

12. Li Q, Mu L, Zhang F, Sun Y, Chen Q, Xie C, et al. A novel fish collagen scaffold as dural substitute. Mater Sci Eng C Mater Biol Appl 2017;80:346-51. [CrossRef]

13. Yamada Y, Boo JS, Ozawa R, Nagasaka T, Okazaki Y, Hata K, et al. Bone regeneration following injection of mesenchymal stem cells and fibrin glue with a biodegradable scaffold. J Craniomaxillofac Surg 2003;31:27-33.

14. Kalantyrskaia MA, Romanenko GF. Diatomite treatment of late ulcerous dermal x-ray lesions. [Article in Russian]. Sov Med 1968;31:112-5.

15. Le TDH, Bonani W, Speranza G, Sglavo V, Ceccato R, Maniglio D, et al. Processing and characterization of diatom nanoparticles and microparticles as potential source of silicon for bone tissue engineering. Mater Sci Eng C Mater Biol Appl 2016;59:471-9. [CrossRef]

16. Recinos G, Inaba K, Dubose J, Demetriades D, Rhee P. Local and systemic hemostatics in trauma: a review. Ulus Travma Acil Cerrahi Derg 2008; $14: 175-81$

17. Ong SY, Wu J, Moochhala SM, Tan MH, Lu J. Development of a chitosan-based wound dressing with improved hemostatic and antimicrobial properties. Biomaterials 2008;29:4323-32. [CrossRef]

18. Gsponer NS, Spesia MB, Durantini EN. Effects of divalent cations, EDTA and chitosan on the uptake and photoinactivation of Escherichia coli mediated by cationic and anionic porphyrins. Photodiagnosis Photodyn Ther 2015;12:67-75. [CrossRef]

19. Kim IY, Seo SJ, Moon HS, Yoo MK, Park IY, Kim BC, et al. Chitosan and its derivatives for tissue engineering applications. Biotechnol Adv 2008;26:1-21. [CrossRef]

20. Dikme O, Ersoy G, Yilmaz O, Dikme O, Gokmen N, Ilyas K. The ef- fect of application of local oxidised cellulose powder on hemostasis time in a rat model with femoral artery bleeding. Acta Medica Mediterr 2015;31:179-82.

21. Crofton A, Chrisler J, Hudson S, Inceoglu S, Petersen F, Kirsch W. Effect of Plasma Sterilization on the Hemostatic Efficacy of a Chitosan Hemostatic Agent in a Rat Model. Adv Ther 2016;33:268-81. [CrossRef]

22. Zhang H, Shahbazi MA, Mäkilä EM, da Silva TH, Reis RL, Salonen JJ, et al. Diatom silica microparticles for sustained release and permeation enhancement following oral delivery of prednisone and mesalamine. Biomaterials 2013;34:9210-9. [CrossRef]

23. Terracciano M, Shahbazi MA, Correia A, Rea I, Lamberti A, De Stefano L, et al. Surface bioengineering of diatomite based nanovectors for efficient intracellular uptake and drug delivery. Nanoscale 2015;7:20063-74.

24. Chao HH, Torchiana DF. BioGlue: albumin/glutaraldehyde sealant in cardiac surgery. J Card Surg 2003;18:500-3. [CrossRef]

25. Kim KD, Wright NM. Polyethylene glycol hydrogel spinal sealant (DuraSeal Spinal Sealant) as an adjunct to sutured dural repair in the spine: results of a prospective, multicenter, randomized controlled study. Spine (Phila Pa 1976) 2011;36:1906-12. [CrossRef]

26. Hoffmann NE, Siddiqui SA, Agarwal S, McKellar SH, Kurtz HJ, Gettman MT, et al. Choice of hemostatic agent influences adhesion formation in a rat cecal adhesion model.J Surg Res 2009;155:77-81. [CrossRef]

27. Lan G, Lu B, Wang T, Wang L, Chen J, Yu K, et al. Chitosan/gelatin composite sponge is an absorbable surgical hemostatic agent. Colloids Surf B Biointerfaces 2015;136:1026-34. [CrossRef]

28. Eryilmaz M, Ozer T, Menteş O, Torer N, Durusu M, Günal A, et al. Is the zeolite hemostatic agent beneficial in reducing blood loss during arterial injury? Ulus Travma Acil Cerrahi Derg 2009;15:7-11.

29. Acosta JA, Yang JC, Winchell RJ, Simons RK, Fortlage DA, Hollingsworth-Fridlund $\mathrm{P}$, et al. Lethal injuries and time to death in a level I trauma center. J Am Coll Surg 1998;186:528-33. [CrossRef]

30. Wang Y, Cai J, Jiang Y, Jiang X, Zhang D. Preparation of biosilica structures from frustules of diatoms and their applications: current state and perspectives. Appl Microbiol Biotechnol 2013;97:453-60. [CrossRef]

\title{
DENEYSEL ÇALIŞMA - ÖZET
}

\section{Yeni bir hemostatik scaffold materyali ve kanama durdurmada fibrin çatı oluşumunun önemi: Deneysel sıçan çalışması}

\section{Dr. İsmail Altıntop, ${ }^{1}$ Dr. Mehmet Tatlı, ${ }^{1}$ Dr. Zeynep Soyer, ${ }^{4}$ Dr. Arzu Hanım Yay, ${ }^{5}$ Dr. Ahmet Öztürk, ${ }^{3}$ Dr. Çiğdem Karakükçü ${ }^{2}$}

\author{
1Sağlık Bilimleri Üniversitesi Kayseri Eğitim ve Araştırma Hastanesi, Acil Tıp Anabilim Dalı, Kayseri \\ ${ }^{2}$ Sağlık Bilimleri Üniversitesi Kayseri Eğitim ve Araştırma Hastanesi, Biyokimya Anabilim Dalı, Kayseri \\ ${ }^{3}$ Erciyes Ünivrsitesi Tıp Fakültesi, Bioistatistik Anabilim Dalı, Kayseri \\ ${ }^{4}$ Erciyes Ünivrsitesi Hakan Çetinsaya Deneysel Araştırma Merkezi, Kayseri \\ ${ }^{5}$ Erciyes Ünivrsitesi Tıp Fakültesi, Histoloji ve Embiryoloji Anabilim Dalı, Kayseri
}

AMAÇ: Kanamayı kontrol etmek için farkı farmakolojik ajanlar geliştirilmekle birlikte; geliştirilen ajanların yara yerinde pıhtı oluşumunu tetiklemesi ve devam ettirmesi için vasokonstrüksiyon, koagülasyon ve scaffold (çatı) etkisi oluşturması önemlidir. Amacımız, cilt yarıkları, vücut dışı yaralanmalar, travmatik kesikler, kendiliğinden ya da cerrahi girişimler sonrası oluşan minör ve majör açık kanamaların durdurulması için kullanılacak ajanların kanama durdurucu özelliği yanında scaffold özelliğinin gösterilmesi amaçlanmıştır.

GEREÇ VE YÖNTEM: Çalışmamız deneysel olarak sıçanlar üstünde yapıldı. Sıçanlarda oluşturulmuş femoral kanama modelimize kanama durdurucuların etkileri incelendi. Araştırmamızda kanama zamanı, scaffold oluşumu, histopatojik etki, SEM analizleri yapıldı.

BULGULAR: Deney modelinde ağılık kaybı kontrol grubunda ortalama $5.0 \pm 1.3 \mathrm{gr}$, kitosan grubunda ortalama $2.9 \pm$ I.I gr, PD grubunda ortalama $2.7 \pm$ I.0 olarak tespit edildi. Deney öncesi ve sonrası ağılık farkı için kontrol grubu ile kitosan ve PD grubu karşılaştırıldığında değişim istatistiksel anlamlı bulundu. Scaffold oluşumu incelenirken gruplar arası karşış̧ıtırma yapıldı ve istatistiksel olarak anlamlı idi. Scaffold oluşumu kitosan grubunda 6 (\%75) tam, 2 (\%25) zayıf olarak tespit edildi. PD grubunda ise 7 (\%87.5) tam scaffold oluşumu, I (\% |2.5) zayıf scaffold oluşumu tespit edildi. Scaffold oluşumu kontrol grubu ile kitosan ve PD grubu ile karşılaştııılıı̆ında sonuç anlamlı idi $(p=0.002)$.

TARTIŞMA: Çalışmamızda PD ile oluşturulan scaffold; uygun bir gözeneklilik ve fibrin çatıya destek sağladığı ve kanamanın yeniden oluşmasını önlediğini ortaya koymuştur. PD'nin scaffold etkisi güçlüdür ve istatistiksel olarak anlamlı bulunmuştur. PD bileşiği kitosan kadar kanama durdurmada etkili bulunmuştur. PD'nin hisopatolojik olarak femoral bölgede hücrelerin ve damarların doğal yapısına zarar vermediği gösterilmiştir. Anahtar sözcükler: Diatomit; fibrin çatı; kanama durdurucu ajan; kitosan.

Ulus Travma Acil Cerrahi Derg 2020;26(2):163-170 doi: 10.14744/tjtes.2019.34359 